\title{
Path of Survivors: An Analysis of Boy Erased and The Miseducation of Cameron Post
}

\author{
Trisha Zoe Tedjakarna \\ English for Creative Industry, Faculty of Languages and Literature, Petra Christian University, \\ Siwalankerto 121-131, Surabaya 60236, INDONESIA \\ E-mail: trishazoe25@gmail.com
}

\begin{abstract}
This study aims to analyse the impacts of conversion therapy and the self-transformation of the main characters in Boy Erased and The Miseducation of Cameron Post, which are two films published post-legalisation of same-sex marriage in America. Both main characters showed signs of self-loathing, decreased authenticity, and feeling anger and disappointment due to conversion therapy. The two characters are first portrayed as victims and survivor of conversion therapy at the end of the film. Jared was shown as a silent victim turned outspoken survivor. Cameron was shown as a rebellious victim and survivor. Both films showed the growth from victims into survivors, which gave a strong, capable and hopeful image of homosexuals and is a contrast from some representation of homosexuals of the past. Despite the similarity in ending up as survivors, the two characters picked different fights.
\end{abstract}

Keywords: Homosexual, Film, Victim, Survivor, Conversion therapy.

\section{INTRODUCTION}

American film is considered the pioneer of film industry and from which a lot of genres were born. Homosexuality is not exempted from the list of subject American cinemas explores. A report by GLAAD (Ramos, 2018) noted the incline from LGBTQ portrayals in film from year 2017 to 2018, which may imply a trend in the film industry. However, despite the seemingly promising improvement, negative representation of homosexuals is still one of the persisting problems. Representation of homosexuals in the past were problematic for being shown as victims or villains, suicidal, self-loathing, predatory, unstable. In addition, lesbians were adorned with traditionally masculine personality and mannerism, and on the other hand, gays were adorned with traditionally effeminate personality and mannerism. Film is a work of art which could not be separated from reality; as Ariel Heryanto (Javanicus, 2017) puts it, film contains prevailing norms in society. This topic becoming more interesting as America has legalized same-sex legalization in 2015, but citizens still has mixed opinions about it.

In this research, I will analyze two films which are titled Boy Erased and The Miseducation of Cameron Post. Boy Erased is a film about a male college student named Jared who is sent to conversion therapy. Jared was outed by a fellow student who raped him, which got him interrogated by his father. He denied the accusation at first, but eventually confessed to his parents. He willingly participates in therapy activities and follows the rules of the place. He is then told to drop out of university and spend more of his time in therapy. Scared of the possibility of staying for undecided amount of time, Jared eventually build up enough courage to oppose the therapy staff. He leaves therapy with the support of his mom, but to the disappointment of his father. After four years, he releases articles on his experience in conversion therapy, and eventually make peace with his father. The Miseducation of Cameron Post is a film about a female high schooler who is sent to conversion therapy after she was caught having sex with a girl. Unlike Jared who confessed, Cameron is sent to the therapy because someone told her aunt about her involvement with the girl. Even though she is willing to enroll in a therapy program, she was not as enthusiastic as Jared in therapy activities nor as submissive as Jared's attitude toward rules and authority. Cameron spends her time rebelling 
Tedjakarna: Path of Survivors: An Analysis of Boy Erased and The Miseducation of Cameron Post

from the therapy. However, one day she found out that she was outed by the very girl she was with through her letter. After the shocking finding, she calls her aunt, who rejects her implicit request to go home. After the succession of rejection from people she knew, she becomes obedient until she finally becomes rebellious once more after a participant harms himself because of his father's rejection. Cameron starts to feel unsafe in their hands and grows angry toward therapy's carelessness and eventually decides to run away with her friends, on their own.

There are a few similarities, just as there are a few differences between the two films. Both films centered around a homosexual protagonist's life and struggle after being sent to sexual conversion therapy by their family members. Both protagonists also entered religionbased conversion therapies, which view homosexuality as sin. However, the two characters have differences, for one, Jared is a college student, making him a few years older than high schooler Cameron. Not only that, Jared lives in 2000s, ten years later compared to Cameron who lives in 1990s. The conversion therapy they joined also have some differences: Jared's therapy, Love in Action, guides its participants mostly with religion and is not scared to physically abuse them; meanwhile Cameron's therapy, God's Promise seems to guide its participants with religion imbued with psychology, and throughout the film it dares not to physically hurt its participants. While Love in Action dared to invite people to punish failed participants by hitting them, the most God's Promise does was putting a foot on top of a participant to restrain them. Love in Action only takes half of Jared's days, while God's Promise forces Cameron to live in the facility. In addition, while the two character underwent transformations from victims into survivors, they survive through different ways and end up with different situation. Jared leaves therapy and thrives with his book on his unpleasant experience in conversion therapy, while Cameron escapes with two fellow participants and heads to the uncertain life on the streets. It is also important to note that the two films were released post-legalization of same-sex marriage, but are set before the legalization. The similarities and the differences, along with the fact that there are still bad depictions of homosexuals despite the increasing amount of it, interested me in analyzing the depictions of homosexuals in these two films.

For this research, I used two theories to analyze the two films: the first theory is sexual conversion therapy's history and technicalities, and the second theory is visual language. Conversion therapy is a practice of attempting to change one's sexuality (Tozer \& McClanahan, 1999). A lot of experts mainly believe that conversion therapy is mainly harmful towards homosexuals (Dessel, 2011). To name a few negative effects of conversion therapy on homosexuals: depression, poor self-esteem, difficulties with intimate relationship, guilt, helplessness, hopelessness, shame, social withdrawal, suicidality, substance abuse, stress, disappointment, self-blame, decreased authenticity to others, increased self-hatred, hostility and blame toward parents feelings of anger and betrayal, loss of friends and protentional romantic partners, problems in sexual and intimacy, sexual dysfunction, high-risk sexual behaviours, a feeling of being dehumanised and untrue to self, a loss of faith, and a sense of having wasted time and resources (National Center for Lesbian Rights, 2018). However, conversion therapy does not only affect homosexuals, but also people's perception of them. Conversion therapy encourages society to think of homosexual as mental illness and that it is curable.

The second theory is Visual language. According to the eleventh edition of Film Art (Bordwell, Thompson \& Smith, 2017), the actual meaning of mise-en-scene is "putting into the scene", and in film making context, it means that what appears in the film frame is a result of directors' setting or control. There are four components in mise-en-scene (Bordwell, Thompson \& Smith, 2017): setting, costume and makeup, lighting, and staging. 


\section{1. JARED: SILENT VICTIM AND OUTSPOKEN SURVIVOR}

Jared underwent two stages of transformation throughout the events in the film. The first transformation happened when he came out to his parents and changed from being defensive (vocal) to receptive (silent). Jared's second transformation happened over the time while he was attending Love in Action and silently disagreeing with the therapy. Jared's second transformation happened when he refused to direct his anger towards the therapy leader to his father. In his second transformation, Jared turned from a silent victim into a vocal survivor.

\subsubsection{Silent Victim}

In the early part of the film and most parts of the flashbacks, Jared's first transformation was shown. After coming out to his parents, Jared tried hard to correct his way and go back to become a good boy in his parents' eyes. Jared is a silent victim and it is evident in the way he listened to his parents, did the therapy seriously and pretended that he was okay.

First of all, as a victim, Jared follows his parents' will obediently in spite of a minor protest at the beginning. Jared's coming out in the beginning of the film is full of him giving up to his parents will. In the scene where Jared was confronted by his father Marshall's associates, Jared was silent, and unable to talk back nor question his parents. He accepted their terms and agreed to go to conversion therapy, after possibly sensing his loss of support from his mother and the possibility of losing the rest of privileges he has. This attitude of Jared is a sign of Jared's loss of authenticity, as he used to be outspoken, but then was silenced with threats of losing his privileges. This scene also shows Jared's guilt towards his sexuality.

Second of all, Jared paid full attention and followed the therapy's program religiously. Jared shows attempts on being a good student. He followed therapy activities which insinuates that homosexuality is sinful and that gay men are weak attentively. He did well in masculine posture training and even practiced it in his room, which means he really tried to follow the therapy well. Other than that, he also takes his assignments seriously. He even asked his mom Nancy to provide him information necessary to complete his assignment. He also followed the rules set by Love in Action and did not question it.

Third of all, Jared does not express his frustration openly. Because of Love in Action's rules, Jared is unable to relate to fellow participants nor can he confide in his mom. When a part of his journal was ripped and kept by conversion therapy staff. After he left the staff, he was shown to be hung up on his journal. It was shown how Jared stopped himself from escalating the situation. Jared also hides his feelings from his mother. The evening of a day when he was frustrated after knowing he might have to stay at Love in Action for a long time, he excused himself from dinner and went for a jog; here, he expressed a mix of anger and frustration. Jared looked nothing like how he is front of people, quiet and obedient. I think Jared's frustration may have been linked with his inability to not like men, which means that he showed signs of selfhate. This also shows that Jared could potentially have problems with intimacy, which is one of the effects of conversion therapy (National Center for Lesbian Rights, 2018). Jared also stayed silent when humiliated by a therapy staff. He was quiet in front of the staff, but as soon as he exited the facility, he immediately shown his frustration by hitting a pillar with his binder. In this scene, Jared is also shown to be lying about his feelings to fellow therapy member. With that, it means that Jared hides his feelings from everyone.

Jared's act of trying to be a good, obedient student and son reflect Mash and Hunsley's (1993) statement on participants' wanting to hide their failure because they have desire to please therapists and fear therapists' disapproval. This may also due to the system of reward and 
Tedjakarna: Path of Survivors: An Analysis of Boy Erased and The Miseducation of Cameron Post

punishment (Ford, 2002) applied by both his parents and the therapy. The example of the system is the moment where Jared was threatened to join a conversion therapy unless he wanted to be stripped of his job, shelter, family and church community. In that scene, there was a small bit of reward for Jared after he agreed to go to conversion therapy; His father's tone became softer, and Nancy stopped crying and finally looked at him again.

Jared's portrayal as a silent victim is quite common in the cinematic history representation of homosexuals. He was shown to be unhappy and feeling guilty, similar to past portrayals of homosexuals (Russo, 1981). However, Jared does not appear effeminate. On the contrary, he is shown loving basketball and games (things which are usually connected to boys). In addition, he does not dress overly femininely nor behave in a way that can be perceived as effeminate.

\subsubsection{Outspoken Survivor}

Even though Jared started off as a silent victim, after facing a few shaming and silent disagreements, he finally saw the therapy for what it really is. Jared became braver and more talkative, and did the opposite of what he had done while he was being a silent victim. As he grew to be less of a silent victim and more of an outspoken survivor, Jared started to break therapy rules, be honest to himself and speak up his mind. When he finally changed into an outspoken survivor, Jared exited the therapy program by causing a ruckus, then Jared wrote articles exposing conversion therapy practice, and he confronted Marshall about having not accepted him.

First, Jared quitted the therapy by rebelling and storming out of the room. In his previous state, he would not dare to pull those actions off. It is a real contrast to the time where he is silently following his parents and the conversion therapy's instruction. Jared grew from defending himself, questioning the therapy leader's method, until he finally outright called them crazy. For a person who believed in conversion therapy's curing capability and as a person who cared a great deal about his image as a good student and son, him defying figures of authority would be terrifying. However, Jared managed to deny the therapy's authority over Jared's fate and form his own opinion.

Second, Jared openly opposed conversion therapy using his writings. Four years after he exited therapy, Jared is shown to have written several articles on his experience in conversion therapy, and has gotten an offer to make a book on the same topic. Getting out of Love in Action was already hard for Jared, not to mention he might have experienced trauma after the therapy, and yet he still found it in him to write about it and tell everyone his experience in it.

Third, Jared confronted Marshall about him not accepting his sexuality. Four years after his experience at conversion therapy, Jared confronted his father who has not changed his mind. in this scene, he was shown to be assertive in addressing the problems between the two of them. $\mathrm{He}$ also mentioned his unwillingness to pretend. Jared ended the scene with him extending an olive branch. The relationship between the two was damaged, but Jared was able to move past that and letting himself be vulnerable by giving his father another chance to grow closer to him. For a person who have been hurt so much, it would be hard to fight their defense mechanism, but Jared was able to do just that.

In Jared's case, it seems that conversion therapy helped him to transform into a survivor. Jared refused to acknowledge a rape incident (where he was the victim) as his sin, and slowly became more and more critical towards the therapy until he finally came to conclusion that the therapy really did not make sense. Acceptance and affirmation are mentioned as one of reasons for the shift in perceiving homosexuality (Silman 2018; Calhoun, 2018), and Nancy 
plays a big part in accepting and affirming Jared's choice to accept his sexuality and defy his father's wish.

\subsection{CAMERON: REBELLIOUS VICTIM, SUBSERVIENT VICTIM AND REBELLIOUS SURVIVOR}

Cameron underwent two transformations, the first one being from a rebellious victim to a subservient victim and the second being from a subservient to a rebellious survivor. Cameron in the first half of the film was a vocal survivor, she was relatively carefree and does not really hide her opposition toward the therapy. After facing rejection from Coley and Ruth, in addition to the therapy finally affecting her, Cameron grew to be more subservient. She did her assignment and hung out with her roommate who was more serious about therapy than Jane or Adam. However, this attitude was short lived, as Cameron changed into a rebellious survivor and escaped the facility with her friends.

\subsubsection{Rebellious Victim}

Cameron has a different personality compared to Jared from Boy Erased. Cameron has a rebellious side to her that make her appear less vulnerable to suggestions. In addition, Cameron seemed to have a better understanding of herself and may be more daring because she is at the rebellious age. Even so, she was still a victim of society and her aunt Ruth who sent her to the therapy. However, the way she refused to play along made her seemed like she was refusing her condition as a victim. Cameron refused to suffer by refusing to answer or share information about her, hanging out with rebels, and doing activities unrelated to therapy.

First of all, Cameron refused to answer or share information. In facing questions, he did not bother to make up a lie, and answered simply with "I don't know". Even when she was pressured to answer, she answered briefly and vaguely. Once, she was about to say too much, but immediately snapped out of it and answered vaguely using a word with broad meaning.

Second of all, Cameron's rebellious and outspoken self probably nurtured due to friends she found in the therapy: Jane and Adam. She was naturally surrounded by believers of the therapy. Cameron's roommate, group therapy classmates, and workmate are all believers. However, Cameron got out of her way to be friends with Jane and Adam, who had bad reputation for being rebels. Cameron could also relate over their shared opposition to therapy.

Third, Cameron did a lot of activities unrelated to the therapy. Compared to Jared whose time is filled with therapy activities and assignments, Cameron barely touched her assignment and stayed outside of therapy discussions as much as she can. She did some activities which are not related to therapy, and some are against the rules such as planting and smoking weed, but some are relatively harmless like Cameron preferring to write a love calculator involving her and Coley (her friend and lover) rather than doing her assignment.

I find Cameron representing homosexuals as rebellious from the beginning is not completely new, but still is refreshing, especially because she is the main character of the film. Rebellious, confident or 'bad girl' lesbians exist in films, but more often as secondary characters or as the love interest of the shy main character. Cameron's attitude at this stage of her transformation is actually, like a teenager but put in the context of sexual conversion therapy. Other than being a rebellious victim or rebellious homosexual who was put under the pressure to become a heterosexual, Cameron is after all, only a rebellious teenager. Because of Cameron's depiction as a teenager, her character may resonate with younger audience. 
Tedjakarna: Path of Survivors: An Analysis of Boy Erased and The Miseducation of Cameron Post

\subsubsection{Subservient Victim}

Despite Cameron's resistance, she eventually experienced an episode of subservice/obedience. Coley singled out Cameron as the source of problem in their forbidden relationship even though she also took initiatives in their relationship. Cameron started to blame herself - which is one of the side effects of conversion therapy (National Center for Lesbian Rights, 2018) and sabotaged her self-confidence as she considered herself as the bad person who tempted and ruined Coley. After reading Coley's letter, Cameron called and asked Ruth to be take her back home but was refused. This rejection from Ruth may also be one of the reasons why she became silent.

As a subservient Victim, Cameron did the opposite of her attitude as a rebellious victim: Cameron hung out with believers of therapy, did her assignments and spent most of her time doing therapy-related activities. This change in Cameron was very drastic and did not last long. From what I have known, it is not typical to have this kind of character development. This stage shows Cameron's loss of authenticity. The three points above showed that Cameron had a complete change of attitude, she has lost her rebellious self.

First, Cameron was shown exercising with her roommate. Cameron had been avoiding Erin to hang out with Jane and Adam. She got offered to exercise with Erin early in the film, but had just taken it after she transformed into a subservient victim.

Second, Cameron was shown working on her iceberg, and it was also shown that her previously almost empty paper got filled up with writings. Cameron is skeptical toward God's Promise's methods, and don't care much about therapy assignments and activities, but after she changed, she immediately did her homework.

Third, she was only seen onscreen with Adam and Jane once. Cameron, whose time had been filled by hanging out and being close with the rebels only shared screen one time during her time as subservient victim. Instead of the rebels, Cameron hung out with her roommate (exercising together) and working with a fellow participant Mark.

Since this film is about conversion therapy, and this certain stage of Cameron's transformation is about the therapy getting into Cameron, I think it can be interpreted as the filmmakers' attempt to show that a rather headstrong, rebellious person like Cameron could also break down, lose hope and go with the stream.

\subsubsection{Rebellious Survivor}

A reason which stopped Cameron from her subservient phase is Mark's incident. A fellow participant Mark experienced a meltdown after being rejected by his father. The night after his meltdown, he was found mutilating his genitals with razor and bleach and Cameron found the remaining blood trails from the incident.

First, Cameron talked back to one of therapy staff member Rick. Even as a rebellious victim, Cameron was not the type of person who would go out of her way to defend homosexuals and openly oppose the therapy; however, in this scene, she was seen to be more in control of the conversation with pursuing the information and blaming therapy staff right directly to one staff member. This is different from her previous passive resistance act.

Second, Cameron confronted the inspector in charge of investigating Mark's incident. In this scene, Cameron, once again, blamed the therapy. She also said that the therapy is harmful because it is a form of mental abuse - in an effort to point out the inspector's ignorance. 
In this scene, Cameron was also shown to be visibly angry-which is interesting since she has almost always donned a neutral face, especially in public.

Third, Cameron planned an escape from the facility with her friends. Escaping from the facility is an act of bravery. If Cameron was not a fighter, and stayed a victim, she would grind her teeth and get on with the program. It was mentioned early in the film that Jane and Adam did not escape even though they knew a way out because escaping means that they have to live on the streets after. The fear is amplified knowing that they will not have anyone to turn to after their escape, and yet they took the chance.

Similar to Jared, God's Promise's unpleasant therapy treatment (Johnston \& Jenkins, 2006) helped Cameron to start resisting therapy again. Therapy staff's carelessness resulting in a participant's self-harm prompted Cameron's rebelliousness again. This point can be connected to suicide of a close friend being the reason for transformation (Brady \& von Leonie, 2019). Cameron's unpleasant experience with the inspector also contributes to her change of heart. She was relatively neutral until the inspector questioned if she was being abused, which made Cameron angry and defend the homosexuals' right. In this case, I think Cameron's knowledge and awareness, helped her in realising that conversion therapy is a form of mental abuse. In addition, while Adam and Jane may not be powerful people who can save Cameron out of therapy like Jared's mom, they are certainly Cameron's source of strength. Jane and Adam were able to provide Cameron with encouragement and sense of belonging and comradeship. This form of support could be the catalyst (Guay, 2014) of Cameron's resistance to the system.

In addition to the external factors, I think Cameron's personality is also a part of the reason she could bounce back and became rebellious survivor. Prior to her time in conversion therapy, Cameron has had a relatively pleasant experience with a girl (Coley), which means that Cameron already has a bit of knowledge of the other side of homosexuality which was not taught in therapy. Cameron also had her rebellious victim phase where she already formed her opinions (with the help of Jane and Adam who encouraged her perspective) on therapy treatments and therapy staff. Her opinions served as knowledge which help her in realising the therapy's fault and snapping out of her obedient phase. Cameron's resilience is also shown in the way she was able to bounce back after she completely into an obedient victim for a while.

\section{CONCLUSION}

In my analysis on the impacts of conversion therapy on the homosexuals in Boy Erased and The Miseducation of Cameron Post and how they survive the therapy, I found and revealed that both Jared from Boy Erased and Cameron from The Miseducation of Cameron Post faced some problems such as loss of authenticity, disappointment, anger, and self-hate, and they were shown surviving from conversion therapy by transforming themselves respectively as a silent victim turned outspoken survivor and as a rebellious victim and survivor. They were both portrayed as victims first: Cameron started as a braver main character as she seemed to have established her identity and acceptance of her attraction to the same sex, while Jared was seen to be continually conflicted and tortured in his search for identity and courage. However, later on Jared continued to fight it openly while Cameron might have lived a quieter life in the end. Both characters tried to fight the system in their own ways. While Jared openly fought conversion therapy through educating and informing people using his writings, Cameron's fight is more about staying alive and holding his belief firmly.

In history of homosexuality depiction, homosexuals had been portrayed as a selfloathing (Walters, 2001, as cited in Baker, 2015), mentally unstable, violent, and suicidal being (Russo, 1981; Baker, 2015), as villains or victims (Nevins, Spry, \& Epstein, Friedman, 1995). However, the two films do not attach those attributes to their main characters. The two 
Tedjakarna: Path of Survivors: An Analysis of Boy Erased and The Miseducation of Cameron Post

characters were portrayed as survivors, and showed happier and more positive depiction of homosexuals. I feel like this is a powerful message which supports and gives strength to homosexuals - that now they are more than the old portrayals of homosexuals as tortured victims. This growth from Jared and Cameron can actually be interpreted as filmmakers attempt to change the old depiction of homosexuals (tortured victim who is fated to be unhappy) into a newer, more positive portrayals of homosexuals (fighter and strong and independent survivor).

\section{REFERENCES}

Brady, K., \& von Leonie, H. (2019, July 28). Surviving 'conversion therapy' for LGBTQ+ people in Germany. Deutsche Welle. Retrieved from https://p.dw.com/p/3Mh6a

Baker, S. (2015). The changing face of gay representation in Hollywood films from the 1990s onwards. The International Journal of Interdisciplinary Cultural Studies, 10(4), 4151. doi: https://doi.org/10.18848/2327-008X/CGP/v10i04/53191

Bordwell, D., Thompson, K., \& Smith, J. (2017). Film art: An introduction (11th ed.). New York, NY: McGraw-Hill Education.

Calhoun, D. (2018, June 14). How i survived 'ex-gay' conversion therapy. Colorlines. Retrieved July 03, 2020, from https://www.colorlines.com/articles/how-i-survived-ex-gayconversion-therapy\#

Dessel, A. (2011). Moving beyond a systematic review of sexual reorientation therapy. Social Work, 56(2), 178-180. Retrieved June 7, 2020, from www.jstor.org/stable/23719371

Ford, J. G. (2002). Healing homosexuals: A psychologist's journey through the ex-gay movement and the pseudo-science of reparative therapy. Journal of Gay \& Lesbian Psychotherapy, 5(3-4), 69-86. doi: https://doi.org/10.1300/J236v05n03_06

Guay, J. (2014, July 15). My hellish youth in gay conversion therapy and how i got out. Time. Retrieved July 10, 2020 from https://time.com/2986440/sexual-conversion-therapygay/

Javanicus. (2017, October 22). Historiografi Indonesia yang rasis. [Video]. YouTube. Retrieved June 8, 2020, from https://www.youtube.com/watch?v=ejEjVA29lls.

Johnston, L. B., \& Jenkins, D. (2006). Lesbians and Gay Men Embrace Their Sexual Orientation After Conversion Therapy and Ex-Gay Ministries. Social Work in Mental Health, 4(3), 61-82. doi:10.1300/j200v04n03_04

Mash, E. J., \& Hunsley, J. (1993). Assessment considerations in the identification of failing psychotherapy: Bringing the negatives out of the darkroom. Psychological Assessment, 5(3), 292-301. doi: 10.1037/1040-3590.5.3.292

National Center for Lesbian Rights. (2018, November 8). Born perfect: The facts about conversion therapy. Retrieved March 23, 2020, from http://www.nclrights.org/bornperfect-the-facts-about-conversion-therapy/

Nevins, S., Spry, C. (Producer), \& Epstein, R., Friedman, J. (Producers/Directors) (1995). The Celluloid Closet [Motion Picture]. United States: Sony Pictures Classics.

Ramos, D.-R. (2019, May 23). GLAAD report shows increase in gay and lesbian representation in major studio films, absence of trans and LGBTQ people of color. Deadline Hollywood. Retrieved December 19, 2019, from https://www.google.com/amp/s/deadline.com/2019/05/lgbtq-representation-studiofilms-glaad-studio-responsibility-index-gay-trans-queer-1202620744/amp/.

Russo, V. (1981). The Celluloid Closet. New York, NY: Harper \& Row.

Silman, A. (2018, August 10). 8 People on Surviving Gay Conversion Therapy. Retrieved July 03, 2020, from https://www.thecut.com/2018/08/8-gay-conversion-therapy-survivorson-cameron-post.html

Tozer, E. E., \& McClanahan, M. K. (1999). Treating the purple menace: Ethical considerations of conversion therapy and affirmative alternatives. The Counseling Psychologist, 27(5), 722-742. doi: https://doi.org/10.1177/0011000099275006 
Walters, S. D. (2001). All the rage: The story of gay visibility in America. Chicago, IL: University of Chicago Press. 